\title{
A Comparative study of financial performance of banking sector in Sri Lanka - An application of CAMEL rating system
}

\author{
Kobika.R
}

\begin{abstract}
Purpose of this study is to compare the financial performance of state and private sector banks. The banking sector of developing countries is different from the developed countries. The banking sector of Sri Lanka plays a vital role in the Sri Lankan Economy specially commercial banks a re playing a major role in the banking sector of Sri Lanka. There are two types of commercials banks in Sri Lanka such as state and private commercial banks here the private commercial banks can be divided into domestic and foreign private commercial banks. The focus of this study is to compare the financial performance of state and private commercial banks using the Capital Adequacy, Assets Quality, Management Soundness, Earnings, Liquidity (CAMEL) rating system in Sri Lanka 2013-2017. Many studies are conducted in different countries to compare the financial performance of banking sector with the use of various statistical methods. In this study CAMEL rating system used to compare the financial performance of banks, it is one of the quantitative techniques and it is widely used in the current world. State banks should focus to increase their financial performance to compete and survive successfully in the current world and also private commercial banks try to achieve their target financial performance for their long survival.
\end{abstract}

Keywords: CAMEL, Financial Performance, Private Banks and State Banks, Rating System.

\section{Introduction}

The banking sector plays an important role in Sri Lankan economy as in other countries in the world. A considerable growth and improvement can be observed recent past in terms of number of banks, number of instruments on offer, range of services provided. There are twenty five licensed commercial banks operating in the country regulated by the Central Bank of Sri Lanka. Ten of these banks are formed locally and the rest are foreign banks operating as branch entities. Two of the local commercial banks are state-owned. The Sri Lankan government and the central bank of Sri Lanka too have introduced several reforms to improve the efficiency and stability of the financial sector. Banking sectors of Sri Lanka is contributing a considerable amount to the economic growth of the Sri Lanka. Business firms and individuals are very familiarly using the cheque in their business transaction due to that commercial banks are much needed in the current environment.

The banking sector has adopted new technologies to a considerable level to improve its efficiency and performance in order to achieve their long term goals. Ability to compete is determined by its financial performance efficiently and effectively. As 
such appraising financial performance is very crucial for all organizations. This is especially important for financial institutions like banks, because it helps to identify the major strengths and weaknesses of the business. Financial analysis also assists to predict the future performance of the banks. The information obtain from financial analysis shows the financial position of the organization, that will be interested by various internal and external stakeholders such as managers, employees, customers, financial institutions, and government.

This study ultimately aim to compare the financial performance of state and private banks using the well-known CAMEL rating system in Sri Lanka which banks were performing during the period 2008-2012. CAMEL frame work includes five crucial dimensions of banking operations under the performance of banking sector. CAMEL rating system is discussed as follows,

Capital Adequacy: The capital adequacy measures the bank's capacity to handle the losses and meet all its obligations towards the customers without ceasing its operations. This can be met only on the basis of an amount and the quality of capital, a bank can access. A ratio of Capital to Risk Weighted Assets determines the bank's capital adequacy.

Asset Quality: An asset represents all the assets of the bank, Viz. Current and fixed loans, investments, real estates and all the offbalance sheet transactions. Through this indicator, the performance of an asset can be evaluated. The ratio of Gross Non-Performing Loans to Gross Advances is one of the criteria to evaluate the effectiveness of credit decisions made by the bankers.

Management Quality: Management soundness state how the management is effectively and efficiently performing in the banks. It is calculated by different composition in this study it includes portion of the operating cost on its profit for the year. Management soundness is a much needed one for every firm to functioning successfully in the market. Here the management is the wholly responsible people on control of the risk and operating cost of the banks.

Earnings: Income from all the operations, nontraditional and extraordinary sources constitute the earnings of a bank. Through this parameter, the bank's efficiency is checked with respect to its capital adequacy to cover all the potential losses and the ability to pay off the dividends. Return on Assets Ratio measures the earnings of the banks.

Liquidity: Liquidity of the banks indicate its ability to meet current liabilities here liquidity is calculated the using of the current ratio. Liquidity is much needed for every firm for their day to day operations. Every bank tries to have sufficient sources of funds on acceptable terms to meet present and anticipated liquidity needs.

\section{Existing empirical findings}

Various authors have assessed the financial strength and weaknesses of financial institutions using various models. Among the models CAMEL model is popular. CAMEL is the model which measures the financial performance of banks in terms of five features, Capital adequacy, Assets quality, Management, Earning quality, and Liquidity. It is used 
frequently by researchers. As such a number of evidences are found from the literature.

Gupta and Verma (2008) examined the competitive analysis of financial performance of private sector banks in India. They found that management of non-performing assets and risks emanating from adverse events are the key to the higher profitability of Indian bank and concluded that transparency and good governance would work as principal guiding force for Indian Banks. Snagmi and Nazir (2010) also analyzed financial performance of major two banks using CAMEL model and highlighted that the position of banks under study sound and satisfactory in terms of their capital adequacy, asset quality, management efficiency and liquidity were concerned. In another study by Mohiuddin (2014) among a sample of commercial banks in Bangladesh using CAMEL parameters found that the bank under study was best at their financial performance during the period of study.

Further, another recent study by Suba and Jogi (2015), evaluating and comparing the performance of two private sector banks HDFC and ICICI in India, found that while there was no significance level of difference between the two selected banks in terms of certain indicators, significance difference was observed between two selected banks in terms indicator of capital adequacy ratio. Another study (Azizi \& Sarkani , 2014) conducted in the context of Mellat Bank in Iran reveal that there is a positive significant relationship between the indices of liquidity, quality of management and earnings with financial performance. However, no relationship was seen between capital adequacy and assets quality with bank financial performance.

Balaputhiran and Nimalathashan (2013) did a comparative study between private and state banking sector in Sri Lanka. The results revealed that all variables of corporate governance are positively correlated with ROE in state banks as well as, in private banks except $\mathrm{BD}$ and $\mathrm{BMF}$ other variables have strong negative relation with ROE, which is significant at five percent level of significance. Jeevarajasingam (2014) has studied on Liquidity and Profitability of Private Banks in Sri Lanka showed that liquidity ratio has strong positive correlation with return on assets. Thayapran and Pratheepan (2014) studied the total factor productivity growth of commercial banks in Sri Lanka. The overall results concluded that comparatively selected private banks are more efficient than state banks in the study period in Sri Lanka.

A comparative study on state and private sector commercial banks in Sri Lanka for the time period of 2008-2012 has been conducted by applying CAMEL rating system (Anojan and Nimalathasan, 2014). In the study they have stated that private sector banks are better than state banks in the performance of capital, earning to the asset quality and management soundness of the banks in Sri Lanka.

Although CAMEL model has been used to measure financial performance by various countries, as far the recent published literature, none of such study seems to be carried out in the Sri Lankan context. Application of CAMEL model in measuring financial performance of Sri Lankan banking sector is very useful. Therefore, the main focus of this study is to 
evaluate comparative ability of financial performance using CAMEL model for the selected banks from government and private banks.

\section{Research objectives}

Main objective of the study is to compare the financial performance of state and private sector selected licensed commercial banks in Sri Lanka and the followings could be considered as specific objectives,

- To rank the selected licensed commercial banks in Sri Lanka according to the CAMEL rating system

- To suggest the selected licensed commercial banks on their financial performance

\section{Methodology}

\subsection{Scope}

Scope of this study is to compare the financial performance of selected State and Private commercial banks which were categorized by Central Bank of Sri Lanka under commercial banks up to 2017. Two state commercial banks were selected for the study such as Bank of Ceylon and Peoples' Bank and four private commercial banks were selected for this study purpose such as Commercial Bank of Ceylon PLC, Hatton National Bank PLC, Sampath bank and Seylan bank

\subsection{Date sources}

In order to fulfill the objectives of the study and to do the analysis of the study, data was collected from secondary source mainly from annual report of the selected banks, which were published by both CSE and respective banks. All the annual report's financial statements have independent auditors report especially State banks financial statements are audited by Auditor General of Sri Lanka and Private
Banks are audited by Chartered Accountants. Normally financial statement of the Sri Lankan banks include statement of income, statement of financial position, statement of cash flow, statement of changes in equity and relevant notes. Here bank's statement of income and statement of financial position has used in this study.

\subsection{Sample design}

This study conducted in Sri Lank. Researchers selected two state and four private banks for this study. There were only two States commercial banks so $100 \%$ sample taken from State commercial banks. There were 22 private commercial banks however only four banks taken to this study according to their performance in the market. Data for the study were collected from 2013 to 2017.

\subsection{Reliability and validity}

Secondary data for this study was taken from audited financial statements of the respective banks as fairly accurate and reliable. Banks financial statement is audited by independent auditor due to the legal requirement State banks are audited by Auditor General of Sri Lanka and private banks are audited by independent auditors who are chartered accountants of Sri Lanka. These data may be considered reliable for the study and the independent auditor gross checking all the transaction of the banks in order to draw opinion on the financial statement.

\subsection{Mode of analysis}

Researcher analyzes banks' data by employing ratio analysis according to the necessity of the CAMEL rating system in this study. Entire analysis is done by personal computer for this 
study and Microsoft Office Excel 2010 was used in order to analyze the data especially compare the financial performance of the banks in the study and draw the conclusion which is well known software in the current practice.

\section{Analysis, Results and Interpretation}

Table 1: Capital Adequacy

\begin{tabular}{lllllll}
\hline Name of Banks & 2013 & 2014 & 2015 & 2016 & 2017 & Average \\
\hline People's Bank & 3.92621782 & 4.233629 & 4.206607 & 4.581155 & 5.279584 & 4.4454385 \\
Bank of Ceylon & 4.834208 & 5.628654 & 5.19577 & 5.562218 & 5.694993 & 6.2722561 \\
Commercial Bank & 10.1366 & 8.937311 & 8.071544 & 7.885333 & 9.418988 & 8.8899546 \\
Hatton National Bank & 10.0829 & 10.56104 & 8.969989 & 8.967234 & 11.32581 & 9.9813939 \\
Sampath Bank & 7.438522 & 7.155116 & 6.686965 & 6.755954 & 8.005264 & 7.2083640 \\
Seylan Bank & 10.11412 & 9.629973 & 8.455325 & 7.800928 & 8.38122 & 8.8763122 \\
\hline
\end{tabular}

Table 1 shows capital adequacy of state and private banks here the ratio indicates that equity capital on total assets of the banks. It was calculated equity capital divide by total assets of the banks. Commercial bank of
Ceylon has high level of capital adequacy ratio also HNB has high ratio than state banks. From the results it is clearly shown that private banks capital adequacy better than state banks.

Table 2: Assets Quality

\begin{tabular}{|c|c|c|c|c|c|c|}
\hline Name of Banks & 2013 & 2014 & 2015 & 2016 & 2017 & Average \\
\hline People's Bank & 75.44229 & 73.69701 & 74.78538 & 73.88789 & 74.89202 & 74.5409174 \\
\hline Bank of Ceylon & 60.7694 & 55.78151 & 52.71923 & 59.9106 & 59.59415 & 57.7549781 \\
\hline Commercial Bank & 67.83817 & 62.55399 & 59.80496 & 62.57561 & 64.29066 & 63.4126769 \\
\hline Hatton National Bank & 68.97069 & 68.6219 & 68.71709 & 68.04407 & 66.93026 & 68.2568033 \\
\hline Sampath Bank & 68.06583 & 69.9887 & 71.83783 & 69.67686 & 70.79387 & 70.0726194 \\
\hline Seylan Bank & 63.46547 & 62.1565 & 65.16514 & 66.29547 & 68.81748 & 65.1800113 \\
\hline \multicolumn{3}{|c|}{$\begin{array}{l}\text { Table } 2 \text { reveals that assets quality of the state } \\
\text { and private banks which shows amount of } \\
\text { loans and advances on the bank's total assets. It }\end{array}$} & \multicolumn{4}{|c|}{$\begin{array}{l}\text { quality ratio in Sri Lanka and } \\
\text { ercial Bank has second low level assets } \\
\text { ratio. According to the table } 2 \text { results }\end{array}$} \\
\hline
\end{tabular}


quality performance however BOC in the better

position of assets quality than other banks

Table 3: Management Soundness

\begin{tabular}{lllllll}
\hline Name of Banks & 2013 & 2014 & 2015 & 2016 & 2017 & Average \\
\hline People's Bank & 75.44229 & 73.69701 & 74.78538 & 73.88789 & 74.89202 & 74.5409174 \\
Bank of Ceylon & 60.7694 & 55.78151 & 52.71923 & 59.9106 & 59.59415 & 57.7549781 \\
Commercial Bank & 67.83817 & 62.55399 & 59.80496 & 62.57561 & 64.29066 & 63.4126769 \\
Hatton National Bank & 68.97069 & 68.6219 & 68.71709 & 68.04407 & 66.93026 & 68.2568033 \\
Sampath Bank & 68.06583 & 69.9887 & 71.83783 & 69.67686 & 70.79387 & 70.0726194 \\
Seylan Bank & 63.46547 & 62.1565 & 65.16514 & 66.29547 & 68.81748 & 65.1800113 \\
& & & & & & \\
\hline
\end{tabular}

Table 3 indicates that management soundness of state and private sector banks which reflects the amount of operating cost on the profit for the year. It was calculated operating cost divide by profit after tax. Results of the table 3, it can be seen that People's Bank has low level of management soundness ratio than other banks as well as Seylan Bank of has second low level ratio than remaining four banks. As a comparison state and private banks has mixed financial performance on liquidity in Sri Lanka.

\section{Table 4: Earnings}

\begin{tabular}{lcccccc}
\hline Name of Banks & 2013 & 2014 & 2015 & 2016 & 2017 & Average \\
\hline People's Bank & 1.05 & 1.8 & 1.8 & 1.7 & 1.9 & 1.29 \\
Bank of Ceylon & 1.4 & 1.6 & 1.7 & 1.9 & 1.7 & 1.66 \\
Commercial Bank & 1.87 & 1.6 & 1.42 & 1.53 & 1.54 & 1.59 \\
Hatton National Bank & 1.5 & 1.7 & 1.6 & 1.8 & 1.8 & 1.68 \\
Sampath Bank & 0.98 & 1.23 & 1.28 & 1.55 & 1.67 & 1.34 \\
Seylan Bank & 1.16 & 1.33 & 1.4 & 1.23 & 1.16 & 1.25 \\
& & & & & & \\
\hline
\end{tabular}


Table 4 states earnings of the state and private banks which consider earnings on the total assets of the banks. Here the researcher only covered ROA, it was calculated through net profit after tax divide by total assets of the banks.
The results show Hatton National Bank has high level of ROA than other banks and Commercial Bank has second level of ROA than state banks. Ultimately private banks have better financial performance than state banks in Sri Lanka.

Table 5: Liquidity

\begin{tabular}{lcccccc}
\hline Name of Banks & 2013 & 2014 & 2015 & 2016 & 2017 & Average \\
\hline People's Bank & 25.2 & 30.26 & 25.9 & 21.7 & 24.1 & 25.4 \\
Bank of Ceylon & 27.7 & 30.8 & 28.2 & 21.6 & 27.2 & 27.1 \\
Commercial Bank & 34.05 & 33.11 & 27.72 & 27.41 & 27.28 & 29.91 \\
Hatton National Bank & 23.32 & 22.81 & 25.09 & 24.23 & 26.29 & 24.35 \\
Sampath Bank & 27.62 & 24.54 & 33.90 & 30.00 & 22.38 & 27.69 \\
Seylan Bank & 26.74 & 27.60 & 27.56 & 22.68 & 23.57 & 25.63
\end{tabular}

Table 5 reveals that liquidity position of the state and private sector banks which shows strength of the liquidity of the banks. It was calculated through current assets divided by current liabilities of the banks. According to the table 5 Commercial bank of Ceylon has high level of liquidity ratio than others and Sampath Bank has second high level ratio than remaining four banks. Ultimately private banks have better financial performance than state banks in Sri Lanka.

Table 6: Final Ranking with Average Ratios

\begin{tabular}{|l|l|l|l|l|l|l|}
\hline & $\begin{array}{l}\text { People's } \\
\text { Bank }\end{array}$ & $\begin{array}{l}\text { Bank of } \\
\text { Ceylon }\end{array}$ & $\begin{array}{l}\text { Commercia } \\
\text { l Bank }\end{array}$ & $\begin{array}{l}\text { Hatton } \\
\text { National } \\
\text { Bank }\end{array}$ & $\begin{array}{l}\text { Sampath } \\
\text { Bank }\end{array}$ & Seylan Bank \\
\hline $\begin{array}{l}\text { Capital } \\
\text { Adequacy }\end{array}$ & 4.4454385 & 6.2722561 & 8.8899546 & 9.9813939 & 7.2083640 & 8.8763122 \\
\hline Rank & $\mathbf{6}$ & $\mathbf{5}$ & $\mathbf{2}$ & $\mathbf{1}$ & $\mathbf{4}$ & $\mathbf{3}$ \\
\hline Asset Quality & 74.540917 & 57.7549781 & 63.4126769 & 68.2568033 & 70.0726194 & 65.1800113 \\
\hline Rank & 4 & & & & & \\
\hline Management & 24.5025 & 28.48652 & 28.81471 & 33.59885 & 27.98184 & 27.4551 \\
\hline
\end{tabular}




\begin{tabular}{|l|l|l|l|l|l|l|}
\hline Soundness & & & & & & \\
\hline Rank & $\mathbf{1}$ & $\mathbf{4}$ & $\mathbf{5}$ & $\mathbf{6}$ & $\mathbf{3}$ & $\mathbf{2}$ \\
\hline Earnings & 1.29 & 1.66 & 1.59 & 1.68 & 1.34 & 1.25 \\
\hline Rank & $\mathbf{5}$ & $\mathbf{2}$ & $\mathbf{3}$ & $\mathbf{1}$ & $\mathbf{4}$ & $\mathbf{6}$ \\
\hline Liquidity & 25.4 & 27.1 & 29.91 & 24.35 & 27.69 & 25.63 \\
\hline Rank & $\mathbf{5}$ & $\mathbf{3}$ & $\mathbf{1}$ & $\mathbf{6}$ & $\mathbf{2}$ & $\mathbf{4}$ \\
\hline Final Rank & $\mathbf{4}$ & $\mathbf{3}$ & $\mathbf{2}$ & $\mathbf{1}$ & $\mathbf{6}$ & $\mathbf{5}$ \\
\hline
\end{tabular}

Table 6 reveals that ranking the banks

private sector banks better than state banks in according to the CAMEL rating system here Hatton National Bank ranked as first according to the capital adequacy and earnings financial performance of the bank, Commercial Bank ranked as first according to the liquidity of the banks and Bank of Ceylon ranked as first according to the asset quality of banks. Overly HNB can be ranked as first according to the above results; Commercial Bank can be ranked as second, Bank of Ceylon and people's Bank respectively third and fourth.

\section{Conclusion and recommendations}

Effective financial performance is much needed for every firm as well as banks. Basically financial performance consider all the aspect of the firm as finance wise such as capital, liquidity, earnings, risk and management soundness of the firm. CAMEL rating system is one of the great systems to compare the financial performance of the banks. Generally CAMEL rating system is a quantitative technique and widely used in various countries. Country's economic development is affected by the amount of banking industry growth in that country (Morteza et, al.,). This study was conducted the aim of the compare the financial performance of the state and private sector banks with the use of CAMEL rating system in Sri Lanka. According to the findings it can be stated that

the performance of capital adequacy, earnings and liquidity position of the banks. The private banks show better performance according to the assets quality and management soundness of the banks in Sri Lanka. Finally it can be concluded that private banks have better financial performance that state banks in Sri Lanka. Furthermore Hatton National Bank is in strong level, Commercial Bank is in the satisfactory level, BOC is in the fair level and People's bank in the marginal level of financial performance.

According to the help of the findings of the study as a researcher can be suggested to the Sri Lankan commercial banking sector to enhance the growth of the banking sector and growth of the Sri Lankan economy.

- In the case of the capital adequacy of the banks, state banks should avoid further more debt capital in the future any capital needed if the bank go debt fund, it will definitely deficient in the case of capital adequacy.

- According to the assets quality People's bank and Sampath Bank should take necessary steps to recover the loans and advances from the customers and from others. It is one of the risks for the banks due to that such banks must go for better decision when they will go to give loan and advances in the future. 
- Management soundness much needed in the case of management soundness, HNB and Commercial bank need to increase the total income of the bank through effective investment ideas and keep well proportion of fund on the banking activities such as loan, pawning and other investment. Those banks should try to reduce its operating cost through avoid over staffs, unnecessary promotion and advertisement activities.

- In the case of bank's earnings, Seylan Bank and People's bank should work hard and sincerely to raise the total income through staff's commitment, creative and effective work, increase the customers through quality \& quick services and investing the funds in high level of return investment and do special necessary promotion and marketing complain. Those banks should take necessary steps to avoid over staffs and try to reduce personnel cost which is the major cost in both banks.

To stipulate the liquidity position the HNB and People's Bank would try to increase in the source of current assets through well recovery of the loan and advances and avoid the invest in the non-current assets and try to reduce current liabilities through avoid short term borrowings.

- Overly the state banks should adopt the new aspects and new high quality and creativity young personnel to create better health and wealth of the banks as well the private banks also take much considerations on their portion of the loans and advances on the assets and management soundness here those banks try to develop appropriate recovery policy and investment policy.

\section{Limitation of the Study}

There are three types of banks such as commercial banks, saving banks and special purpose banks and 22 private sector commercial banks. In this study only considered commercial banks and four private commercial banks and here the researcher covered the financial year from 2013 to 2017. All the data of the study collected from respective bank's financial statement which has independent auditors report however there is very little error. Here the bank's statement of financial position is not clearly stated the noncurrent assets and current assets for the study requirement the researchers have categorized and defined current assets according to the fair knowledge of the financial accounting.

\section{References}

Andires.A.M , Cocris.V and Ursu .S.G (2012) Determinants of Bank Performance in CEE countries, REBS Review of Economics and Business Studies, 5(2), 165-177.

Azizi.M and Sarkani.Y.A (2014) Review financial performance of MELLAT Bank According to CAMEL Model, A journal of multidisciplinary research, 3(1), 32-42.

Baalaputhiran.S and Nimalathasan.B (2013) Corporate Governance and Banking Performance: A comparative study between private and state banking sector in Sri Lanka, European Journal of Business and Management, 5(20), 92-100.

Chakraborty.J, Salam.F and Rabbany.G (2015) financial analysis of Islamic bank in Bangladesh, International journal of Economics Finance and Management, 3(2), 99106.

Guptha. R.CA (2014) An Analysis of Indian public sector Banks using CAMEL Approach, 
IOSR Journal of Business and Management, 16(1), IV, 94-102.

Guptha. S and Verma .R (2008) Comparative analysis of Financial Performance of private sector banks in India: Application of CAMEL model, Journal of Global Economy, 4(2), 160184.

Ibrahim. M (2014) Comparative Performance of Tow Banks in United Arab Emirates, Research Journal of Accounting and Finance, 5(21), 24-30.

Jeevarajasingam .N (2014) A study on Liquidity and profitability of Private Banks in Sri Lanka, Research Journal of Finance and accounting, 5(21),165-174.

Mohiuddin .G (2014) Use of CAMEL model: A study of Financial Performance selected Commercial Banks in Bangladesh, Universal Journal of Accounting and Finance. 2(5), 151 160.

Nimalathasan .B (2009) Determinants of Key Performance of (KPIS) of Private sector banks in Sri Lanka. An Application of Explortory Facter analysis. The Annals of The "Ştefan cel Mare" University of Suceava. Fascicle of The Faculty of Economics and Public Administration, 9(2), 9-17.

Anojan, V. and Nimalathasan, B., (2014). A Comparative Study of Financial Performance of State and Private Sector Commercial Banks IN Sri Lanka: An Application of CAMEL rating system, ICCM 